\title{
Self-Service Technology in Retailing. The Case of Retail Kiosks*
}

\author{
Hira Cho ${ }^{* *}$, Susan S. Fiorito ${ }^{* * *}$
}

\begin{abstract}
Retailers are adopting self-service technologies (SSTs) to improve the quality of service. Self-service technologies indicate any technological application, but the most typical SST is interactive kiosks which refer to computer workstations for public access. Kiosks have widely been used for banking (ATM) and airline checkins.

Now kiosks are shown in diverse retail sectors, including food service, supermarkets, department stores, specialty stores, drug stores, bookstores, and entertainment. The range of service varies depending on retailers' goal.

However, the retail application is not always positively received. Thus it is vitally important that retailers understand the inherent problems and strategic issues of kiosks as a SST.

Successful kiosks can deliver financial returns to the company and also impact consumer satisfaction and retention.
\end{abstract}

Keywords: Retail; Retail Kiosks; Self-Service Retailing; Retail Channel Structure; Innovation; Global Markets

\section{Self-Service Retailing and Competition}

As customer service is an essential factor in the current market place, retailers are adopting self-service technologies (SSTs) to improve the quality of service. Technological interfaces enable companies to delight their customers instantly by allowing them to solve their problems using technology (Bitner et al., 2002). Selfservice technologies indicate any technological application, but the most typical SST is interactive kiosks which refer to computer workstations for public access (Rowley and Slack, 2003). Kiosks have widely been used for banking (ATM) and airline check-ins. Another popular use is for hotel service such as automated checkin and check-out facilities, automated room service ordering systems, automated

\footnotetext{
* Invited Article

** Assistant Professor of Merchandising, Oklahoma State University (hirac@ okstate.edu)

**** Professor of Retail Technologies, Florida State University (sfiorito@fsu.edu)
}

Edited by: ISTEI - University of Milan-Bicocca

ISSN: $1593-0319$

Cho Hira, Fiorito Susan S., Self-Service Technology in Retailing. The Case of Retail Kiosks, Symphonya. Emerging Issues in Management (symphonya.unimib.it), n. 1, 2010, pp. 43-55

http://dx.doi.org/10.4468/2010.1.05cho.fiorito 
message services and automated housekeeping services. Now kiosks are shown in diverse retail sectors, including food service, supermarkets, department stores, specialty stores, drug stores, bookstores, and entertainment. An example of retail kiosks is a self scanning device and a self check-out system in a supermarket. The range of service varies depending on retailers' goal. While some kiosks are used simply to check the price, other kiosks can be designed to deliver products and/or store information and transaction services. Other retail usages are for management (e.g., recruitment of employees) and educational applications (e.g., Colgate provides educational videos for dental hygiene through kiosks in retail stores).

Kiosks can bring a competitive advantage to retailers (Tung and Tan, 1998). However, the retail application is not always positively received. In the entertainment business, changes in the technological environment influences the sustainable success of kiosks' application. For example, movie download kiosks will be grow for sometime but eventually disappeared because the Internet will replace what kiosks now do for consumers (Murphy, 2007). Thus it is vitally important that retailers understand the inherent problems and strategic issues of kiosks as a SST. Successful kiosks can deliver financial returns to the company and also impact consumer satisfaction and retention. Few previous studies have concentrated on self scanning devices or check-out systems in supermarket settings or have examined the influence on consumer commitment toward the firm. Yet, the previous studies did not clearly identify the success factors in different retail settings. Furthermore, previous literature rarely profiled a successful case of retail kiosk use.

Therefore, this study introduces a case company which has a history of financial success and positive consumer response with the adoption of retail kiosks. Through in-depth interviews with employees at the case company, their strategies were analyzed. Before introducing the company, we reviewed the literature on retail kiosks.

\section{Retail Kiosks: Winners but Not All of Them}

Since several US and UK cataloguers tested experimental kiosk use in the early 1990's (Rowley, 1995), kiosks have been widespread in retailing, particularly, for the past few years (Moerloose et al., 2005). Previously, kiosks used in retail applications were rare compared with the use for banking and airport check-ins (Ferriolo, 2003). However, presently kiosks are found at different retail locations such as supermarkets, drug stores, and restaurants. The global self-service market is projected to reach $\$ 24.7$ billion by 2010 , maintaining the annual growth rate of $17 \%$ (Howell, 2006). The growth of general SSTs fuels the increase of retail kiosks. As people have more experience with one application of an SST, they will likely use other SSTs for different applications. Service for ATMs in banking is so common nowadays; approximately $75 \%$ of airline check-ins is handled by customers through Internet web pages or stand alone kiosks. While people are accustomed to technology based self-service, they will seek similar experiences shopping, which demand retailers' adoption of kiosks. 
The benefit of SSTs is their efficiency and effectiveness in improving customer service (Bitner et al., 2000). Utilizing kiosks, retailers can deliver fast and customized services and provide convenient shopping experiences (Meuter et al., 2000; Walker et al., 2002). Consumers can pick-up pre-ordered drugs through kiosks even after the store is closed. At a supermarket, using a self check-out kiosk, customers can conveniently pay for the merchandise without standing in a long waiting line. Customers can order food and beverages through kiosks located at their table in a restaurant. In a deli store, when the order is ready, customers then can receive a text message to their cell phone letting them know to pick up their order. Kiosks also can provide information for products (the image, price, availability, and location) and stores (location and operation hours). Some kiosks feature information pull-up systems using key words or conditions (Murphy, 2008). Supermarkets can offer unique information such as health content and recipes using stand-alone kiosks (Murphy, 2007). As a whole, these features can distinguish one retailer from another. From a companies' perspective, kiosks are the cost effective tool to reduce labour costs. According to Forrester Research, airline firms can save \$3.52 for each customer who uses kiosks instead of personnel at a check-in counter (Kivat, 2004). Kiosks work as salespersons within a store. Retailers can deliver advanced customer service with fewer employees while not losing productivity. Therefore, utilizing kiosks can create an advantage to retailers in a very competitive environment (Tung and Tan, 1998).

However, adopting kiosks does not necessarily result in a positive outcome. Uncomfortable feelings toward technology, lack of human interactions, risks of service failure and employee resentment are often cited as the downside of SSTs (Curran et al., 2003). Probably, because of the problems, only about a half of consumers expressed their satisfaction with this self-service experience (Alcock and Millard, 2006). Individuals' tendency in using a new technology was an important driver in behavioural intentions toward SSTs (Lin and Hsieh, 2006). Lack of human interaction is another problem of SSTs, which may be more significant in a high-service-context business such as hotels. Hotel guests felt kiosks were useful but felt employee service was more important (Beatson et al., 2006). It may be because the guests prefer personal contact in relating room conditions or services. Actually, just 10 to $25 \%$ of hotel guests use kiosks to checkin or out when it is available (Stellin, 2006). Employees' support is also important in the use of self check-out kiosks in a supermarket (Anitsal and Paige, 2006). That is, coordinated human interactions are essential for the successful operation of retail kiosks (Rowley, 1995). Well-trained employees can provide quick and effective assistance when customers have problems while using kiosks. In this way, retailers can reduce possible service failure in the use of kiosks.

Beside the inherent problems of kiosks as a SST, retailers need to be concerned with other related issues. A documented failure describes the importance of the visibility of kiosks. Sephora, a leading global beauty retailer, once located kiosks within their stores but they were not attracting consumer attention (Alexander, 2000). The kiosk was placed in the back of the store and customers did not even notice their existence nor were encouraged to use them. More recently, one of Canada's largest bookstores, Indigo Books \& Music, launched its kiosk program but customer response did not meet expectations (Murphy, 2008). When the 
company relocated kiosks to high customer traffic areas and redesigned the appearance of the kiosks, the number of users increased significantly. These practical examples show the importance of location and attention for the successful utilization of kiosks (Rowley, 1995).

To briefly summarize, kiosks are being used in retailing and show great potential for success. However, this success does not mean that all companies will successful when using kiosks. Facilitating kiosks are costly. The basic interactive kiosk is approximately $\$ 25,000$ with PCs and the price increases for touch screens and other customized features. In addition, there will be other costs for printers and high quality display screens, which range from $\$ 2,000$ to $\$ 10,000$; while the software fee ranges from $\$ 3,500$ to $\$ 20,000$ and the licensing fee per kiosk ranges from $\$ 150$ to $\$ 500^{1}$. In order to compensate for this investment, retailers need to adopt winning strategies.

\section{What are Successful Retail Kiosks?}

Gaining financial benefits are the most obvious success factors for retail operations. However, it is often difficult to measure the return on investment (ROI) for kiosks (Murphy, 2007); which can be compared to estimating the revenue created by a single, specific employee. Other than the financial evidence, previous studies investigated the success of kiosks using different measures. While research on retail kiosks is sparse, previous studies were conducted mainly in relation to consumer adoption of kiosks in the context of airline service (Chang and Yang, 2007; Liljander et al., 2006), banking (Littler and Melanthiou, 2006) and overall use of SSTs (Lin and Hsieh, 2006). Those studies identified individuals' characteristics or perceptions of the technology as the significant determinants of consumer adoption. These findings may need further empirical research in a retail context; however there is no question that consumer adoption as an indicator of initial success is vitally important. Because of the innovativeness and unconventional features of kiosks, consumer adoption is an important issue. The sustainable success, however, is measured when customers who have tried kiosks are satisfied with the service and intend to commit future purchases to that retailer.

Beatson et al. (2006) questioned if kiosks affect consumer satisfaction with the organization and commitment to the service provider. Commitment was delineated into affective, temporal, and instrumental commitment; they are represented by positive emotion, individuals' expectation, and losses from terminating the relationship, respectively (Kim and Frazier, 1997; Beatson et al., 2007). Analyzing 241 surveys from the guests of a hotel, researchers found that experiences of kiosks positively related to the satisfaction and commitment intention toward the hotel. For a comparison, the impact of personal service was also examined and the results showed that personal service was a more important determinant of satisfaction and commitment. This result confirmed that kiosks are useful but human factors are still important for the success of kiosks.

Few studies are available regarding the impact of retailers' kiosks adoption on consumer commitment toward the firm. A limited number of studies focused on self-scanning devices or check-out systems. An early study (Dabholkar et al., 2003) 
investigated the determinants of consumer adoption of self-scanning devices in a supermarket but did not examine the consequences to consumer behavior. Similarly, Anitsal and Paige (2006) conducted a study of consumer adoption and quality perception of self check-out systems which are used in the U.S retail grocery stores. The researchers emphasized a pleasant environment, audible instruction, and employee supporting services for positive consumer responses. An additional study (Marzocchi and Zammit, 2006) collected data from users of selfscanning devices at a major Italian supermarket chain located in Northern Italy. The researchers analyzed 353 samples and found that sense of control and enjoyment significantly influenced satisfaction with the self-scanning device. They also found that satisfied customers were willing to say positive things about the store and to visit the store more frequently.

In summary, the success of retail kiosks may be determined by customer adoption initially but consumer satisfaction and commitment will be a more meaningful indicator, as well as positive financial returns. Most previous studies of kiosks were not fully focused on retail use and few researchers investigated the influence of factors on the success of retail kiosks; in other words, the impact of kiosks on consumer commitment. Few studies of retail kiosks were available and those that were conducted were focused on a specific function of the kiosk and in a very specific retail setting; that is, a self-scanning devices or check-out systems in supermarkets. The application of retail kiosks is diverse and kiosks are now being used in different retail sectors. Successful strategies of retail kiosks should be discussed regarding diverse foci of kiosk service and in different retail sectors. Considering this research gap, this study is focused on a US based department store which uses kiosks for a variety of services.

\section{A Profile of a Company and the In-depth Interview Procedure}

In order to learn of strategies for retail kiosks through the practice and identity of potential success factors, a company was selected and in-depth interviews were conducted with employees at that company. In-depth interviews are an appropriate research method when there is not a sufficient amount of information about the subject matter (Bonoma, 1985). Little is known about the success factors for retail kiosks; thus, in-depth interviews focusing on one company were expected to provide insightful implications. The company name and interviewees' names are confidential. We briefly introduce the company and its kiosk operation before describing the interview procedure.

The company has annual sales of approximately $\$ 1 B$ in U.S. currency from over 560 retail store sites all in the U.S. The company is composed of several branches, including department stores and outlets. The specialized product categories include apparel, footwear, gifts items and house wares. The target customers range from young to older adults. Customer service is an important philosophy of this company. One branch of the company installed kiosks within its 80 department stores in the southern area of the U.S. The company first introduced kiosks to their customers in 1999. The main reason they installed kiosks was to assist customers in looking for their shoe size. In the beginning, the kiosks had very limited functions 
(i.e., searching for shoe sizes), and the locations of the systems were only at shoe zones in very few stores. These kiosks brought immediate and positive attention to the stores, which led the company to extend the use of kiosks. Thus the number of stores with kiosks has been continuously increased and kiosks now offer a variety of services. In 2007, all stores in the company had two to five kiosks. Currently customers can use the kiosks to find their products by brand, size or color, to check prices, to place orders and pay for these orders using their credit cards. While some kiosks provide an Internet access, the company does not install the Internet network. Kiosks are located in the main part and throughout the stores, such as in the shoe department, misses department, women's sportswear, men's sportswear area, home or children's department, and are located by the check-out counters. The location of each kiosk is indicated by store signs, usually overhead, for easy identification. The kiosk systems are composed of a computer workstation, monitor, key board, mouse, and a printer.

A researcher visited the headquarters of the company and interviewed five (5) employees of the company late in 2007. The purpose of the interviews was to identify the factors that influence the successful operation of the kiosks, not to generalize the findings; thus, a small and purposive sample was recruited for the interview. Based on the experience and knowledge of the kiosks, five individuals were chosen. Interviewee A was a female corporate executive who was involved in pursuing and helping to design the in-store kiosk since the company adopted the system in 1999. Other interviewees (B, C, D, and E) were three males and one female store managers who worked for the company for three to four years. Interview A was conducted at the corporate office, while the other interviews were handled at three different stores. A set of semi-constructed questions was developed before the interviews. The questions were focused on the motivation to use in-store kiosks, the growth in past and future plans, current use and the general productivity of the system, and challenges or barriers they faced. The questions are listed below. Each interviewee read and signed an informed consent form and then participated in the interview which lasted from 40 - 60 minutes. All interviews were tape recorded, transcribed and then analysed by two researchers.

\section{- In-depth interview questions}

- What made your company decide to invest in kiosk technology?

- What is your company's growth plan for kiosk installations?

- How many customers typically use kiosks each year? Is the number increasing or decreasing each year and by what percentage?

- What percentage of kiosk use can be attributed to selling merchandise as opposed to simply informing the customer about your merchandise and services?

- Why do you use kiosks in your business?

- What is your general evaluation of the use of kiosks?

- Do you have any challengers or barriers in operating kiosks in your stores? 


\section{Findings from the In-Depth Interviews}

\subsection{Kiosks as a Means of Creating Profits and Committed Customers}

Current researchers contend that kiosks have the potential to create profit and positive customer relationships. Interviewee A indicated that kiosks contribute about two percent of the entire sales of the company, which they likened to adding another store to the company. In 2007 the average number of units per shipment via the kiosk was 1.2 and the average dollar per order was \$22 in U.S. currency. Interviewee A also stated the sales through the kiosks have increased each year. The company had an eight percent sales growth in 2007 compared with the previous year. In addition, interviewees $\mathrm{B}$ and $\mathrm{C}$ remarked that most customers know kiosks are available within the store and the number of kiosk users is increasing. The company collected consumer feedback through quick surveys on their kiosks and customer comment cards. The users of kiosks responded that the system is quick, fast and useful and presented a high level of satisfaction with the system and the store. The interviewees answered that kiosks were the means of increasing consumer commitment and loyalty toward the company.

We know our customers are loyal because the kiosk has helped them (Interviewee A).

$\square$ Most of the customers that come into the store use the system for something; either it's for looking up prices or checking and ordering merchandise from another store... (Interviewee B).

$\square$ I think for the most part customers are satisfied with the kiosks... If there is a problem when an older customer uses the kiosk employees usually help them through it. So, they're usually ok with using it (Interviewee C).

\subsection{Strategies for the Success of Retail Kiosks}

Statements from the interviewees provided five categories of strategic focus which led to the success of the company's kiosks operation: interface design, accessibility, employee readiness, promotion and fulfillment. Each category will be introduced by accompanying direct quotations from the interviews when appropriate.

Interface design. Rowley (1995) suggested that the interface design is one of the important factors in the use of kiosks in retailing. A well-designed interface should be evaluated in terms of the functional features from the users' perspective. The functional features will determine the efficient and effective work to complete the information search or transaction on the kiosks. The company designed the interface with a simple but useful layout, which helps customers stay focused on 
what they want. The user friendly design can appeal to diverse customers including the older customers who have very basic experience with computers.

$\square$ Not having a lot of distractions caused by many things going on at the same time helps customers not to get lost. Customers can buy something from the kiosk in less than a minute. It's a fast process. We didn't offer too much with it. It keeps customers focused (Interviewee A).

$\square$ It's pretty easy for some of our older customers that are not computer literate because it's really just a keyboard and a mouse. If they know how to use a keyboard, which most of them do, they can just type in their request. (Interviewee D).

Interface design of the kiosks also should meet their customers' needs and wants which changes over time. Kiosks this company provided have a variety of functions such as price check-up, searching brands or sizes, and ordering merchandise. Those features need to be updated continuously in order to meet the shifting consumer requirements due to evolving retail trends and an ever changing technology environment. Updating kiosks with an improved interface design was one of the important concerns to the company.

$\square$ We're going to update the look, the feel, and some the technology behind the interface design so the searching process is faster (Interviewee A).

Accessibility. Accessible kiosks are mainly determined by their location. A good location increases visibility and therefore the number of users, as we previously discussed with the examples of Sephora and Indigo Books \& Music. From its experience, the company was well aware of the importance of the kiosk's location. The company achieved spontaneous success when they initially installed kiosks in the shoe department, which has one of the highest customer traffic areas in the store. Thus, most stores in this company placed at least one kiosk in the shoe department. Interviewee D stated another popular spot for the kiosk, which was near the check-out counter.

$\square$ If we have long lines at our registers and the customer wants to know what the price of an item is because it's a discounted item and they cannot calculate the reduced price in their head, then we tell them you can always go to one of our three kiosk systems we have and just scan the ticket and you can get the exact price. You will see customers standing on line at the kiosk system when we have some major sales and all the registers are also very busy. (Interviewee D).

Interviewee B mentioned that the return desk could be another popular spot for kiosks. Currently the company does not locate kiosks in this area but the place was suggested as a potentially good selling opportunity. 
When customers return merchandise sometimes they want to reorder the item in a different size, or color versus merely returning item. If we have a kiosk at the return counter it would be a little bit faster for customers to get both the return and the purchase taken care of in one location (Interviewee B).

Employee Readiness. Successful kiosks are designed with many human factors in mind (Anitsal and Paige, 2006; Beatson et al., 2007; Rowley, 1995). Although kiosks are designed to off services created by consumers, employee assistance is still an integral part for kiosk success. Through the failure of their sister company that also adopted kiosks, this company learned the importance of employee training. The kiosk training program for the company is required for all the employees. Well trained employees encourage customers to use kiosks and help customers whenever they have problems while using kiosks. In this way, more customers appreciate kiosks and the company can effectively prevent service failures caused by difficulties with the system. Additionally, as more customers rely on kiosks, the company could increase productivity of employees.

$\square$ Its very user friendly, but some people are still afraid of computers...if they need help we show them so they can do it by themselves (Interviewee E).

Rather than employees having to look up a price for a customer they can actually direct the customer to the kiosk. Then the associates can do something else and take care of other customers (Interviewee B).

In order to motivate the employees' active involvement in the training program, the company provided incentives to employees who used kiosks more frequently and generated higher customer orders from kiosks through their assistance.

$\square$ We evaluate our employees on a monthly basis... how many kiosks orders they've fulfilled in the past month. Employees are expected to be able to use the kiosks and help customers use them (Interviewee C).

Promotion. The company aggressively announced the availability of kiosks to their customers. The kiosks are featured in their advertisements and catalogs. Also, throughout the stores, the company makes regular announcements about the kiosks. Within the stores, customers are repeatedly reminded of the availability of kiosks which increased the number of customers who try the kiosks.

$\square$ We do have a PA system (music play system). The music will stop, and over our PA system we announce 'go to the kiosks to find items that you can't find in your size or color.' (Interviewee D).

Additionally, in order to encourage the use of kiosks, the company provides free shipping when the order is over $\$ 20$ in U.S. currency. The company also offers a 
free gift wrapping service. These strategies induce more customers into the store to shop through kiosks.

$\square$ Anything under \$20 there is a shipping charge. But there are no shipping charges over $\$ 20$ and the merchandise arrives in about 3-4 days. That's a tremendous function and advantage for the customer (Interviewee $C$ ).

Fulfilment. Fulfilment is referred to as one of the most expensive and critical operations but also as one of the most integral parts in improving customer service in multi channel shopping (Porter, 2001). Accurate and timely delivery can be a competitive advantage to a company. According to a survey the company conducted, most of the customers generally were satisfied with the delivery of orders through kiosks. A high fulfilment rate (96\%) for the company supports the survey results. An employee remarked that failure of delivery results from the inaccuracy of inventory, which is caused by store managers' mistakes but not a structural problem of the company.

We advertise we ship in 72 hours but most times we ship it a lot less than that (Interviewee B).

Customers are surprised how fast their orders get to them...They think every store should do it... The negative comments would be if they placed an order and they didn't get it and they thought they should have. (Interviewee A).

\section{Conclusion}

Self-service technologies are emerging in retailing; retailers have adopted kiosks to produce better customer services. Kiosks for retail applications have a huge potential but the success factors are not yet clear. A company was selected for this study that successfully operates kiosks in a department store setting and analyzed their strategies that led to their success. From the in-depth interviews with five employees at the company we found five key success factors. They were:

1. Interface design: well designed interface which is functional and easy to use;

2. Accessibility: visible location for easy access;

3. Employee readiness: trained and motivated employees who can effectively serve kiosks users;

4. Promotion: store advertisement and announcement to encourage kiosk use;

5. Fulfilment: fast delivery with no failures.

It was evident that kiosks at the case company created a financial return as a result of satisfying and retaining customers. Thus, this study suggests that five factors may influence consumer commitment toward the company. Satisfaction may mediate the relationship. Satisfaction was an antecedent of consumer loyalty (Mano and Oliver, 1993). A study of SSTs suggested the experiences with SSTs would increase consumer satisfaction which in turn positively affects commitment 
(Eriksson and Nilsson, 2007). As shown in Figure 1 and the accompanying propositions, each of the factors: interface design, accessibility, employee readiness, promotion, and fulfilment influenced customer satisfaction (P1-P5). Consumer satisfaction is proposed to have two levels, satisfaction with the kiosks and satisfaction with overall service. All five factors affect satisfaction with a kiosk (P1a-P5a) and satisfaction with a store (P1b- P5b). Both satisfaction levels directly affect consumer commitment toward a store (P6-P7).

Figure 1: Impact of Retail Kiosks on Consumer Satisfaction and Commitment



Proposition 1: Interface design of retail kiosks influences consumer satisfaction with kiosks (a) and stores (b)

Proposition 2: Accessibility of retail kiosks influences consumer satisfaction with kiosks (a) and stores (b)

Proposition 3: Employee readiness of retail kiosks influences consumer satisfaction with kiosks (a) and stores (b)

Proposition 4: Promotions of retail kiosks influences consumer satisfaction with kiosks (a) and stores (b)

Proposition 5: Fulfilment of retail kiosks influences consumer satisfaction with kiosks (a) and stores (b)

Proposition 6:Satisfaction with retail kiosks positively influences consumer's intention to a commitment to a store.

Proposition 7: Satisfaction with a store positively influences consumer's intention to a commitment to a store.

Importantly, this conceptual model proposes a future study to be empirically tested. First of all, measures of each of five factors should be developed. With these five measures the causal relationships between the concepts could be tested. This study only focused on the success factors but the negative factors could also be considered in a following study. The interviewees provided the barriers or challenges to the kiosk's operation, such as speed of the data download, equipment maintenance, and regular information and system updates. This aspect was not a part of this research however it could be a focus for future studies. The significance of this study is the exploration of the success factors for multifunctional retail kiosks in the context of a department store which has not been attempted in previous studies. Finally, the kiosks in this company exemplify the maximized utilization of retail kiosks in a department store setting. While other department stores in the U.S. use kiosks with limited functions (i.e., price checkup), this company provides a variety of services, such as product search by brands, sizes, and colours and transaction services. For the company, a kiosk actually can serve 
as a sales person conducting multiple tasks. This illustrates the possibility of kiosks to not only other department stores, but also to different retail sectors.

\section{Bibliography}

Alcock, T. and Millard, N., Self-service-but is it Good to Talk?, BT Technology Journal, vol. 24, n.1, 2006, pp. 70-78. http://dx.doi.org/10.1007/s10550-006-0022-0

Alexander B., Shopping; theKKiosk, where Brick Meets Click, The New York Times, 13 December, 2000, p. 18.

Anitsal I., Paige R.C., An Exploratory Study on Consumer Perceptions of Service Quality in Technology-Based Self-Service, Services Marketing Quarterly, vol. 27, n. 3, 2006, pp. 53-67. http://dx.doi.org/10.1300/J396v27n03_04

Beatson A., Coote L.V., Rudd J.M., Determining Consumer Satisfaction and Commitment through Self-Service Technology and Personal Service Usage, Journal of Marketing Management, vol. 22, n. 7/8, 2006, pp. 853-882. http://dx.doi.org/10.1362/026725706778612121

Beatson A., Lee N., Coote L.V., Self-service Technology and the Service Encounter, The Service Industries Journal, vol. 27, n. 1, 2007, pp. 75-89. http://dx.doi.org/10.1080/02642060601038700

Bitner M.J., Brown S.W., Meuter M.L., Technology Infusion in Service Encounters, Journal of the Academy of Marketing Science, vol. 28, n. 1, 2000, pp. 138-149.

http://dx.doi.org/10.1177/0092070300281013

Bitner M.J., Ostrom A.L., Meuter M.L., Implementing Successful Self-Service Technologies, Academy of Management Executive, vol. 16, n. 4, 2002, pp. 96-109. http://dx.doi.org/10.5465/AME.2002.8951333

Bonoma T.V., Case Research in Marketing: Opportunities, Problems, and A Process, Journal of Marketing Research, vol. 22, 1985, pp. 199-208. http://dx.doi.org/10.2307/3151365

Chang H., Yang C., Do Airline Self-Service Check-In Kioks Meet the Needs of Passengers?, Tourism Management, vol. 29, n. 5, 2008, pp. 980-993. http://dx.doi.org/10.1016/j.tourman.2007.12.002

Curran J.M., Meuter M.L., Surprenant C.F., Intention to Use Self-Service Technologies: a Confluence of Multiple Attitudes, Journal of Service Research, vol. 5, n. 3, 2003, pp. 209-224. http://dx.doi.org/10.1177/1094670502238916

Dabholkar P.A., Understanding Consumer Motivation and Behavior Related to Self Scanning in Retail, International Journal of Service Industry Management, vol. 14, n. 1, 2003, pp. 59-95. http://dx.doi.org/10.1108/09564230310465994

Eriksson K., Nilsson D., Determinants of the Continued Use of Self-Service Technology: the Case of Internet Banking, Technovation, vol. 27, n. 4, 2007, pp. 159-167. http://dx.doi.org/10.1016/j.technovation.2006.11.001

Ferriolo S., The Key to Kiosks, Catalog Age, vol. 20, n. 7, 2003, pp. 103-108.

Howell D., The New Customer Service, Chain Store Age, vol. 82, n. 11, 2006, pp. 114.

Kim K., Frazier G.L., On Distributor Commitment in Industrial Channels of Distribution: a Multicomponent Approach, Psychology and Marketing, vol. 14, n. 8, 1997, pp. 847-877. http://dx.doi.org/10.1002/(SICI)1520-6793(199712)14:8<847::AID-MAR6>3.0.CO;2-E

Kivat B., May You Help You?, Time, 6 September, 2004, p. 101. 
Liljander V., Gillberg F., Gummerus J., Riel A.V., Technology Readiness and the Evaluation and Adoption of Self-Service Technologies, Journal of Retailing and Consumer Services, vol. 13, n. 3, 2006, pp. 177-191.

http://dx.doi.org/10.1016/j.jretconser.2005.08.004

Lin J.C., Hsieh, P., The Role of Technology Readiness in Customers' Perception and Adoption of Self-Service Technologies, International Journal of Service Industry Management, vol. 17, n. 5, 2006, pp. 497-517.

http://dx.doi.org/10.1108/09564230610689795

Littler D., Melanthiou, D., Consumer Perceptions of Risk and Uncertainty and the Implications for Behavior Towards Innovative Retail Services: The Case of Internet Banking, Journal of Retailing and Consumer Services, vol. 13, n. 6, 2006, pp. 431-443.

http://dx.doi.org/10.1016/j.jretconser.2006.02.006

Mano H., Oliver R.L., Assessing the Dimensionality and Structure of the Consumption Experience: Evaluation, Feeling, and Satisfaction, Journal of Consumer Research, vol. 20, 1993, pp. 451-466. http://dx.doi.org/10.1086/209361

Marzocchi G.L., Zammit A., Self-Scanning Technologies in Retail: Determinants of Adoption, The Services Industries Journal, vol. 26, n. 6, 2006, pp. 651-669. http://dx.doi.org/10.1080/02642060600850790

Meuter M.L., Ostrom A.L., Roundtree R.I., Bitner M.J., Self-Service Technologies: Understanding Customer Satisfaction with Technology-Based Service Encounters, Journal of Marketing, vol. 64, n. 3, 2000, pp. 50-64. http://dx.doi.org/10.1509/jmkg.64.3.50.18024

Moerloose C., Antioco M., Lindgreen A., Palmer R., Information Kiosks: the Case of the Belgian Retail Sector, International Journal of Retail \& Distribution Management, vol. 33, n. 6, 2005, pp. 472-490. http://dx.doi.org/10.1108/09590550510603651

Murphy S., Kiosks 411, Chain Store Age, vol. 83, n. 1, 2007, p. 68.

Murphy S., Kiosk Control, Chain Store Age, vol. 84, n. 1, 2008, p. 69.

Porter M.E., Strategy and the Internet, Harvard Business Review, vol. 79, n. 3, 2001, pp. 63-78.

Rowley, J., Multimedia Kiosks in Retailing, International Journal of Retail and Distribution Management, vol. 23, n. 5, 1995, pp. 32-40. http://dx.doi.org/10.1108/09590559510089212

Rowley J., Slack F., Kiosks in Retailing: The Quiet Revolution, International Journal of Retail and Distribution Management, vol. 31, n. 6, 2003, pp. 329-339. http://dx.doi.org/10.1108/09590550310476060

Stellin S., Self-Service Sleeping, Fast Company, vol. 107, 2006, p.106.

Tung L.L., Tan J.H., A Model for the Classification of Information Kiosks in Singapore, International Journal of Information Management, vol. 18, n. 4, 1998, pp. 255-256. http://dx.doi.org/10.1016/S0268-4012(98)00014-0

Walker R.H., Craig-Lees M., Heker R., Francis H., Technology-Enabled Service Delivery: An Investigation of Reasons Affecting Customer Adoption and Rejection, International Journal of Service Industry Management, vol. 13, n. 1, 2002, pp. 91-106. http://dx.doi.org/10.1108/09564230210421173

\section{Notes}

${ }^{1}$ http://smallbusiness.yahoo.com/r-article-a-40944-m-6-sc-42-interactive_kiosks_buyers_guide-i 